\title{
FaDu cell characteristics induced by multidrug resistance
}

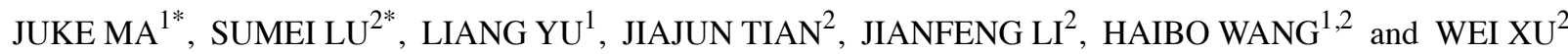 \\ ${ }^{1}$ Department of Otolaryngology - Head and Neck Surgery, Provincial Hospital \\ Affiliated with Shandong University, Jinan 250021; ${ }^{2}$ Institute of the Eye and Otolaryngology, \\ Shandong Clinic Research Institute, Jinan 250021, P.R. China
}

Received May 11, 2011; Accepted July 8, 2011

DOI: 10.3892/or.2011.1418

\begin{abstract}
The major obstacle to tumor chemotherapy is drug resistance. In the present study, we investigated the characteristics of FaDu cells (a hypopharyngeal carcinoma cell line) with multidrug resistance (MDR) induced by Taxol. The resistant cell line, $\mathrm{FaDu} / \mathrm{T}$, was grown by exposing normal $\mathrm{FaDu}$ cells to escalating concentrations of Taxol stepwise for over 12 months. The multidrug resistant sensitivities of the $\mathrm{FaDu} / \mathrm{T}$ cells to cisplatin (DDP), 5-fluorouracil (5-FU), doxorubicin (Dox) and vincristine (VCR) were investigated by methyl-thiazolyl-tetrazolium (MTT) assay. Cell apoptosis was measured by acridine orange and Hoechst 33342/propidium iodide double staining. Cell cycle distribution and the cell apoptosis index were quantified using flow cytometry. Reverse transcription-polymerase chain reaction (RT-PCR) was conducted to determine the mRNA levels of the MDR-related genes MDR1/ $\mathrm{ABCB} 1$ and BCRP/ABCG2. Western blotting was used to assay the expression of MDR1/ABCB1 and BCRP/ABCG2 and the apoptosis-related proteins caspase-3, Bcl-2 and Bax. Compared with the FaDu cells, the drug resistance of $\mathrm{FaDu} / \mathrm{T}$ cells to DDP, 5-FU, Dox and VCR was increased 8.99-, 21.96-, 31.42- and 10.00-fold, respectively. The percentages of $\mathrm{FaDu} / \mathrm{T}$ cells in the G0/G1 and G2/M phases were increased while the cell percentage in the $\mathrm{S}$ phase decreased as compared with the percentages of FaDu cells. The anti-apoptotic ability increased prominently, as the index of apoptosis decreased. Furthermore, caspase-3, Bcl-2 and Bax expression was altered accordingly to resist apoptosis in the FaDu/T cells. MDR1/ABCB1 expression increased significantly at both the mRNA and protein levels, while BCRP/ABCG2 expression appeared to inversely affected, i.e. decreased, in a concentration-dependent manner. These findings may provide theoretical support for the prevention of MDR in clinical cancer chemotherapy.
\end{abstract}

Correspondence to: Dr Wei Xu or Dr Haibo Wang, Institute of the Eye and Otolaryngology, Shandong Clinic Research Institute, Jinan 250021, P.R. China

E-mail:xwhns@yahoo.com.cn

E-mail: whbotologic797@163.com

*Contributed equally

Key words: FaDu, multidrug resistance, apoptosis, MDR1/ABCB1, BCRP/ABCG2

\section{Introduction}

Hypopharyngeal carcinoma, one of the most common malignancies in the head and neck region, results in substantial morbidity and mortality annually. Despite the fact that multimodal approaches have been applied to treat this tumor, the survival rate has not considerably improved during the last two decades $(1,2)$. Traditionally, the main treatment option for primary hypopharyngeal carcinoma is surgical resection (3). This strategy, however, has evolved from the point of view of pure treatment to maximum preservation of hypopharyngeal function, laying emphasis upon the quality of life of these patients. Thus, the standard approach for treatment for these patients is still chemotherapy.

A large number of chemotherapeutic agents are currently in use. Paclitaxel $\left(\mathrm{Taxol}^{\circledR}\right)$ was first approved by the Food and Drug Administration (FDA) for the treatment of refractory ovarian cancer in 1992 but demonstrated activity against head and neck squamous cell carcinoma (HNSCC) (4). Yet, the effect of Taxol for HNSCC is still far from satisfactory. An important limitation is the occurrence of multidrug resistance (MDR), by which cancer cells escape the toxic effect of most commonly used cancer drugs in spite of their different chemical structure and different mechanism of intracellular activity (5). Drug concentrations targeted to cells decrease and the sensitivity of cells decline, both of which lead to chemotherapeutic failure and limited clinical effect of chemotherapy. Thus, elucidation of the underlying molecular mechanisms leading to MDR and therapy failure is crucial (6).

With the aim to elucidate the mechanism of MDR, we carried out the present study using the human hypopharyngeal carcinoma cell line FaDu. A multidrug resistant cell line to Taxol $(\mathrm{FaDu} / \mathrm{T})$ was established by exposing normal FaDu cells to escalating concentrations of Taxol stepwise for over 12 months. The main characteristics between the $\mathrm{FaDu}$ and $\mathrm{FaDu} / \mathrm{T}$ cells were investigated. Our results showed that, compared with $\mathrm{FaDu}$ cells, the percentage of $\mathrm{FaDu} / \mathrm{T}$ cells in the G0/G1 phase and their anti-apoptotic ability were both increased. Expression of caspase-3, Bcl-2 and Bax was altered accordingly to resist apoptosis in the $\mathrm{FaDu} / \mathrm{T}$ cells. Multidrug resistance-related genes MDR1/ABCB1 increased and BCRP/ ABCG2 decreased to counteract the Taxol toxicity in $\mathrm{FaDu} / \mathrm{T}$ cells. These findings may provide theoretical support for the prevention of MDR in clinical cancer chemotherapy. 


\section{Materials and methods}

Cell culture and the establishment of resistant cell line $F a D u / T$. The human hypopharyngeal carcinoma cell line $\mathrm{FaDu}$ was obtained from the American Type Culture Collection (ATCC). Media and serum were purchased from Gibco (USA). Chemotherapeutic drugs cisplatin (DDP), 5-fluorouracil (5-FU), doxorubicin (Dox) and vincristine (VCR) were obtained from Sigma. Anti-ABCB1, -ABCG2, -caspase-3, -Bcl-2, -Bax and - $\beta$-actin antibodies were from Santa Cruz Biotechnology. All other agents were from Sigma (St. Louis, MO, USA). FaDu cells were cultured as a monolayer in Dulbecco's modified Eagle's medium (DMEM) containing $10 \%$ fetal calf serum, $100 \mathrm{U} / \mathrm{ml}$ penicillin and $100 \mathrm{mg}$ streptomycin at $37^{\circ} \mathrm{C}$ in a humidified atmosphere composed of $95 \%$ air and $5 \% \mathrm{CO}_{2}$.

The resistant cell line, $\mathrm{FaDu} / \mathrm{T}$, was developed by continuous exposure of $\mathrm{FaDu}$ cells to stepwise escalating concentrations of Taxol ${ }^{\circledR}$ (Bristol-Myers Squibb Co.) for over 12 months. The initial concentration was determined using the $\mathrm{IC}_{25}$ of Taxol in FaDu cells by MTT. In order to ensure the optimum establishment of the resistant cell line $(\mathrm{FaDu} / \mathrm{T})$, stepwise escalating concentrations of Taxol (5-200 nM for over 12 months) were used continuously as medium content in the progression of the culture, and the dead cells were discounted every 48-72 $\mathrm{h}$ by replacement with new medium containing Taxol. Cell passage was carried out just until achieving cell confluency, and $\mathrm{FaDu} / \mathrm{T}$ cell lines resistant to different concentrations of Taxol were preserved at various times. $\mathrm{FaDu} / \mathrm{T}$ cells were labeled according to their resistance to Taxol at various concentrations, such as ' $\mathrm{FaDu} / \mathrm{T}-200 \mathrm{nM}$ ' which stands for the resistant cell line $\mathrm{FaDu} / \mathrm{T}$ whose tolerance to Taxol was $200 \mathrm{nM}$.

Assessment of cell viability. Methyl-thiazolyl-tetrazolium (MTT) assay was employed to assess the drug resistant sensitivities of $\mathrm{FaDu} / \mathrm{T}-200 \mathrm{nM}$ cells. The cells $\left(15 \times 10^{4} / \mathrm{ml}\right)$ subcultured in a 96-well cluster (Corning, USA) were treated with different concentrations of Dox, VCR, 5-FU and DDP for $72 \mathrm{~h}$. MTT $(5 \mathrm{mg} / \mathrm{ml}, 20 \mu \mathrm{l})$ was added to each well $4 \mathrm{~h}$ prior to the indicated time points. After 4 -h of incubation at $37^{\circ} \mathrm{C}$, the medium was removed, and the precipitate was dissolved in dimethyl sulfoxide (DMSO). The optical density (OD) values were measured at $570 \mathrm{~nm}$ using an ELISA reader (Multiskan MK3). The relative cell viability was calculated according to the following formula: Relative cell viability $(\%)=\mathrm{OD}_{\text {experiment }}$ $\mathrm{OD}_{\text {control }} \times 100\left(\mathrm{OD}_{\text {blank }}\right.$ was considered as zero). The $\mathrm{IC}_{50}$ was defined as the concentration required to decrease the relative viabilities of cells to $50 \%$ of that of the control (no drug) value.

Analysis of the cell growth curve. $\mathrm{FaDu}$ and $\mathrm{FaDu} / \mathrm{T}-200 \mathrm{nM}$ cells $\left(10 \times 10^{4} / \mathrm{ml}\right)$ were subcultured in a 96-well cluster, and the $\mathrm{OD}_{570} \mathrm{~nm}$ values were measured as described above every $24 \mathrm{~h}$ for 6 days. Experiments were repeated three times.

Morphological observation. $\mathrm{FaDu}, \mathrm{FaDu} / \mathrm{T}-200 \mathrm{nM}$ and $\mathrm{FaDu}$ cells treated with Taxol $(200 \mathrm{nM})$ for $24 \mathrm{~h}$ were seeded $\left(15 \times 10^{4} /\right.$ well) in 24-well dishes containing $1 \mathrm{ml}$ culture medium to observe the morphological changes. Cells were washed twice with phosphate-buffered solution (PBS), fixed using 95\% alcohol for $10 \mathrm{~min}$, and stained with $0.01 \%$ acridine orange for
$5 \mathrm{~min}$, or with Hoechst $33342(10 \mu \mathrm{g} / \mathrm{ml})$ and propidium iodide (PI) $(50 \mu \mathrm{g} / \mathrm{ml})$ at $37^{\circ} \mathrm{C}$ for $30 \mathrm{~min}$. Morphological changes were examined by fluorescence microscopy.

Flow cytometric analysis of cell cycle distribution and apoptosis. The cell cycle distribution and apoptosis in the FaDu, FaDu/T-200 nM and FaDu cells treated with Taxol (200 nM) for $24 \mathrm{~h}$ were analyzed by flow cytometry. In brief, cells $\left(15 \times 10^{4} / \mathrm{ml}\right)$ were trypsinized and washed with PBS, respectively. Cells were then pelleted by centrifugation at $1000 \mathrm{rpm}$ for $5 \mathrm{~min}$ and resuspended at a concentration of $1 \times 10^{6}$ cells/ $\mathrm{ml}$ in staining solution $(50 \mu \mathrm{g} / \mathrm{ml} \mathrm{PI}$ and $100 \mu \mathrm{g} / \mathrm{ml}$ RNase A). After incubation at $4^{\circ} \mathrm{C}$ in the dark for $30 \mathrm{~min}$, cells were analyzed using an Epics XL flow cytometer (Beckman Coulter Co., Miami, FL, USA). The proportions of cells at G0/G1, S and G2/M phases were analyzed by the Multicycle software program (Beckman Coulter).

For assessment of apoptosis, Annexin V-FITC and PI were used. After trypsinization, cells were resuspended in binding buffer $(20 \mu \mathrm{l})$ containing Annexin V-FITC $(5 \mu \mathrm{l}, 20 \mu \mathrm{g} / \mathrm{ml})$ and PI $(10 \mu \mathrm{l}, 20 \mu \mathrm{g} / \mathrm{ml})$ for at least $10 \mathrm{~min}$ at room temperature, and then binding buffer $(300 \mu \mathrm{l})$ was added before analysis with the System II, version 3.0 (Beckman Coulter).

Reverse transcription-PCR. Total RNA was extracted using TRIzol (Invitrogen). The reverse transcription reaction was performed using the ExScript RT reagent kit (Takara, Dalian, China) in a final volume of $20 \mu \mathrm{l}$ containing $1 \mu \mathrm{g}$ total RNA, $4 \mu \mathrm{l}$ 5X ExScript buffer, $1 \mu \mathrm{l}$ dNTP mix, $1 \mu \mathrm{l}$ Oligo(dT) primer, $0.5 \mu 1$ ExScript RTase, $0.5 \mu 1$ RNase inhibitor, and RNase-free water to a volume of $20 \mu \mathrm{l}$. The reverse transcription reaction was performed at $42^{\circ} \mathrm{C}$ for $15 \mathrm{~min}$, and the reaction was terminated by heating at $95^{\circ} \mathrm{C}$ for $2 \mathrm{~min}$. PCR was performed following the instructions of Takara $\mathrm{Taq}^{\mathrm{TM}}$ under the following conditions: pre-degeneration at $95^{\circ} \mathrm{C}$ for $3 \mathrm{~min}$, degeneration at $95^{\circ} \mathrm{C}$ for $60 \mathrm{sec}$, renaturation at $58^{\circ} \mathrm{C}$ for $45 \mathrm{sec}$, and elongation at $72^{\circ} \mathrm{C}$ for $60 \mathrm{sec}$, for a total of 25 cycles. All experiments were conducted 3 times. The primers were as follows: MDR1/ ABCB1: forward 5'-CTGCTCAAGTTAAAGGGGCTAT-3' and reverse 5'-AACGGTTCGGAAGTTTTCTATT-3'; BCRP/ ABCG2: forward 5'-GGTCTCAACGCCATCC-3' and reverse 5'-GAGTCTGCCACTTTATCCA-3'.

Western blot analysis. Total protein was extracted using radioimmunoprecipitation buffer (RIPA), a protein lysis buffer, according to standard protocols. The Bradford method was used to determine the protein concentration of the supernatant. Samples (40 $\mu \mathrm{g}$ of total protein each) were analyzed with Western blotting using the primary antibodies (MDR1/ABCB1 1:400, mouse anti-human; BCRP/ABCG2, 1:200, mouse antihuman; caspase-3 1:200, rabbit anti-human; Bcl-2 1:200, rabbit anti-human; Bax 1:200, rabbit anti-human; actin, 1:2000, mouse anti-human). The bands of MDR1/ABCB1, BCRP/ABCG2, caspase-3, Bcl-2, Bax and actin were visualized at apparent molecular weights of 170, 70, 32, 26, 23 and $43 \mathrm{kDa}$, respectively. The relative OD ratio was calculated with NIH software Image $\mathrm{J}$ by comparison with actin in three experiments.

Statistics. Data are presented as mean \pm standard error of the mean (SEM). Statistical calculations were performed using 

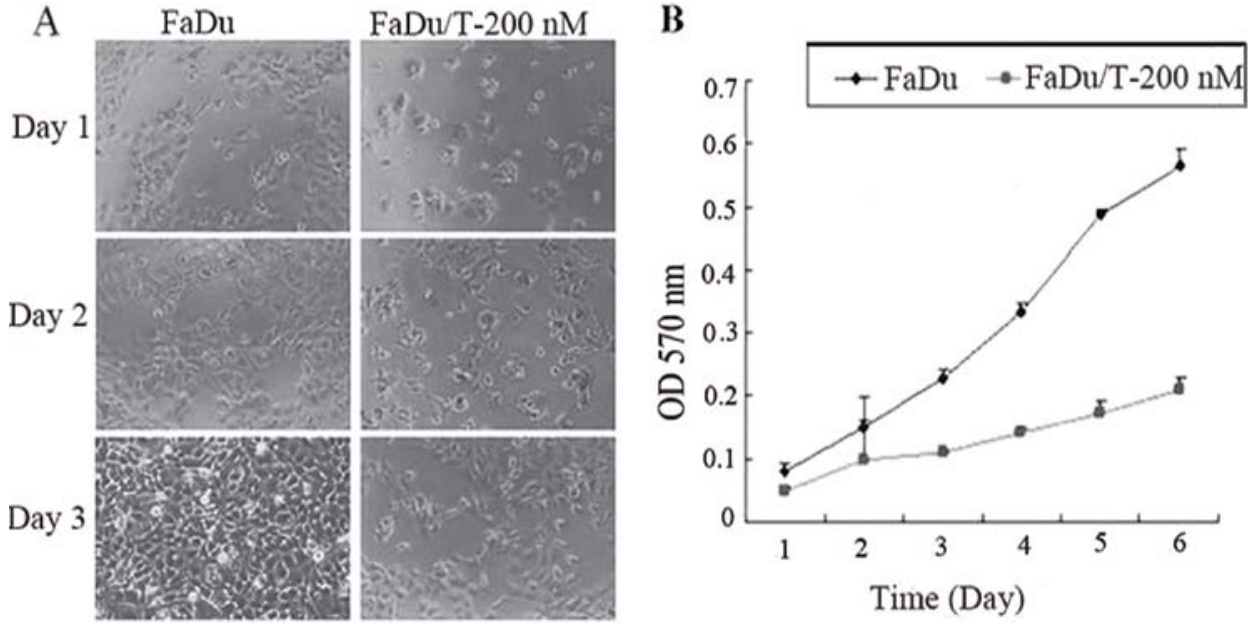

Figure 1. A Taxol-resistant cell line FaDu/T was established. Morphological observation and MTT assay were conducted for growth curve analysis. (A) Morphological observation of FaDu and FaDu/T cells every $24 \mathrm{~h}$ for 3 days. (B) Cell growth was assessed every $24 \mathrm{~h}$ for 6 days.

SPSS16.0 software package. One-way analysis of variance (ANOVA) was applied for the analyses; P-values $<0.05$ were considered significant.

\section{Results}

Establishment of a Taxol-resistant cell line FaDu/T and growth curve analysis. We established $\mathrm{FaDu} / \mathrm{T}$ by exposing normal FaDu cells to escalating concentrations of Taxol stepwise for over 12 months. FaDu/T showed a marked change in cellular morphology with many elongated cell dendrites, and slow growth was observed (Fig. 1A). The growth curves for $\mathrm{FaDu}$ and $\mathrm{FaDu} / \mathrm{T}$ cells are shown in Fig. 1B. The resistant cells grew more slowly than the parental cells $(\mathrm{P}<0.05)$.

Cross-resistance profiles of the FaDu/T cells. Chemotherapeutic drugs of different categories including Taxol, Dox, VCR, 5-FU and DDP were used to evaluate the different resistances of the $\mathrm{FaDu} / \mathrm{T}$ cells. As shown in Table $\mathrm{I}$, the $\mathrm{IC}_{50}$ values for Taxol in the $\mathrm{FaDu}$ and $\mathrm{FaDu} / \mathrm{T}$ cells were $0.13 \pm 0.02$ and $15.32 \pm 3.22 \mu \mathrm{M}$, respectively. FaDu/T cells were 117.85 fold more resistant to Taxol than the parental cells. Our results further indicated that the $\mathrm{FaDu} / \mathrm{T}$ cells also had crossresistance to DDP, 5-FU, DOX and VCR, with 8.99-, 21.96-, 31.42- and 10.00-fold resistance, respectively.

Morphological changes between FaDu and FaDu/T cells. Morphological changes were examined in normal FaDu cells, FaDu cells treated with Taxol $(200 \mathrm{nM})$ for $24 \mathrm{~h}$ and FaDu/T$200 \mathrm{nM}$ cells. As illustrated in Fig. 2, using acridine orange (AO) staining, normal FaDu cells exhibited a polygonal shape, while cells treated with Taxol (200 nM) for $24 \mathrm{~h}$ became rounded and exhibited cytoplasmic contraction and chromatin condensation. Apoptotic bodies, the main morphological characteristic of apoptosis, were also present. However, FaDu/T cells showed a similar morphology to that of the normal $\mathrm{FaDu}$ cells, with intact polygonal nuclei.

For the Hoechst 33342 and PI double staining, blue intact nuclei indicated normal cells, red staining was interpreted as necrosis, while blue nuclear fragmentation was an indication
Table I. Comparison of the chemosensitivity of the FaDu and $\mathrm{FaDu} / \mathrm{T}-200 \mathrm{nM}$ cell lines.

\begin{tabular}{|c|c|c|c|}
\hline & \multicolumn{2}{|c|}{$\mathrm{IC}_{50}($ means $\pm \mathrm{SD})$} & \multirow[b]{2}{*}{ RI } \\
\hline & $\mathrm{FaDu}$ & $\mathrm{FaDu} / \mathrm{T}$ & \\
\hline \multicolumn{4}{|l|}{ Drug } \\
\hline Taxol $(\mu \mathrm{M})$ & $0.13 \pm 0.02$ & $15.32 \pm 3.22^{\mathrm{a}}$ & 117.85 \\
\hline $\mathrm{DDP}(\mu \mathrm{g} / \mathrm{ml})$ & $2.81 \pm 0.57$ & $25.25 \pm 3.78^{a}$ & 8.99 \\
\hline $5-\mathrm{FU}(\mu \mathrm{g} / \mathrm{ml})$ & $15.85 \pm 3.61$ & $347.99 \pm 46.95^{\mathrm{a}}$ & 21.96 \\
\hline $\operatorname{Dox}(\mu \mathrm{M})$ & $1.88 \pm 0.59$ & $59.07 \pm 9.03^{\mathrm{a}}$ & 31.42 \\
\hline $\operatorname{VCR}(\mu \mathrm{M})$ & $6.70 \pm 2.31$ & $66.97 \pm 4.84^{\mathrm{a}}$ & 10.00 \\
\hline
\end{tabular}

$\mathrm{FaDu}$ and $\mathrm{FaDu} / \mathrm{T}$ cells were exposed to different concentrations of Taxol, DDP, 5-FU, Dox and VCR, respectively for $72 \mathrm{~h}$, and then the relative survival rates were detected by MTT. $\mathrm{IC}_{50}$ values were used to evaluate the cross-resistance sensitivities of $\mathrm{FaDu} / \mathrm{T}$ cells. $\mathrm{RI}$, resistance index. ${ }^{\mathrm{a}} \mathrm{P}<0.05$.

of apoptosis. As shown in Fig. 2, compared with normal FaDu cells, red nuclei and blue nuclear fragmentation were detected in the cells treated with Taxol (200 nM) for $24 \mathrm{~h}$. However, the $\mathrm{FaDu} / \mathrm{T}$ cells (with tolerance to Taxol at $200 \mathrm{nM}$ ) showed a similar morphology to that of the normal FaDu cells, with blue intact nuclei. Our data indicate that $\mathrm{FaDu} / \mathrm{T}$ cells exhibit anti-apoptosis when stimulated by Taxol.

Cell cycle distribution of the FaDu and FaDu/T cells. As shown in Fig. 3, compared with the normal FaDu cells, the percentages of $\mathrm{FaDu} / \mathrm{T}-200 \mathrm{nM}$ cells in the G0/G1 and $\mathrm{G} 2 / \mathrm{M}$ phases were higher - G0/G1: FaDu 38.0 $3.12 \%$,

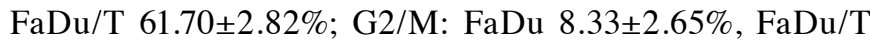
$19.54 \pm 3.49 \%$, while the percentage of $\mathrm{FaDu} / \mathrm{T}-200 \mathrm{nM}$ cells in the $\mathrm{S}$ phase was inversely reduced: $\mathrm{FaDu} 53.67 \pm 5.66 \%$, $\mathrm{FaDu} / \mathrm{T} 18.76 \pm 2.47 \%$. These results explain the reason for the slow cell growth of $\mathrm{FaDu} / \mathrm{T}$ cells as mentioned above. 


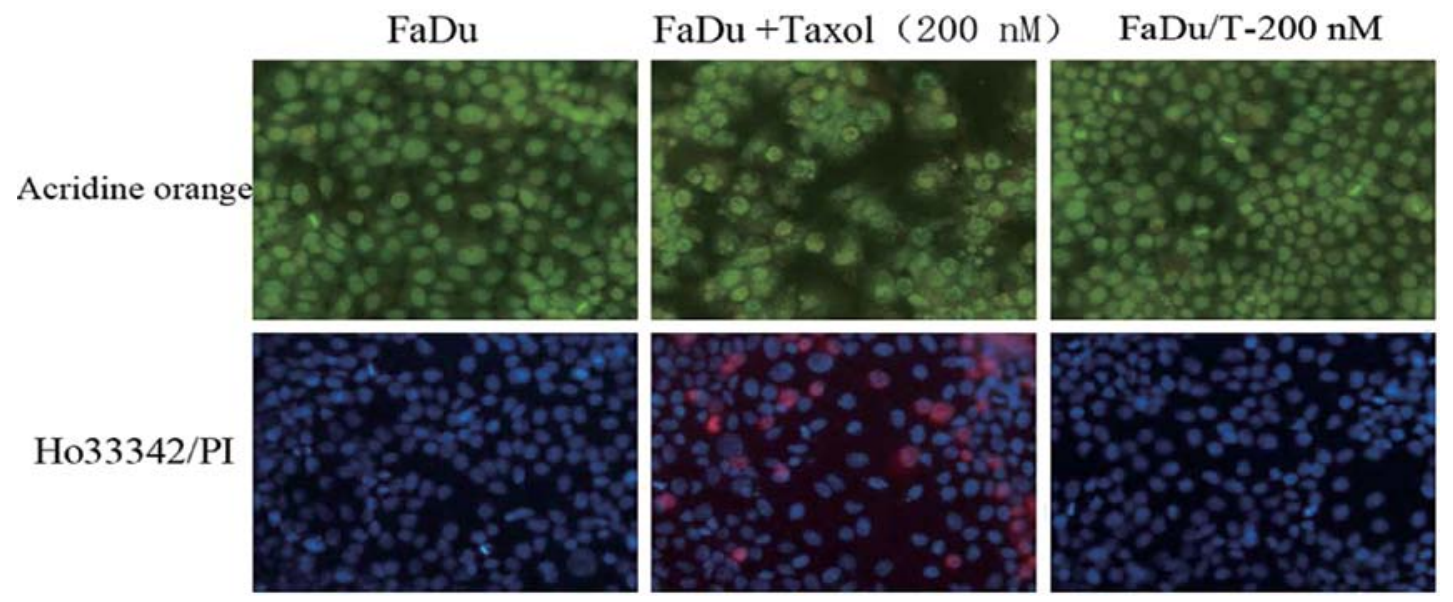

Figure 2. Morphological changes in FaDu cells, FaDu cells stimulated by Taxol at $200 \mathrm{nM}$ for $24 \mathrm{~h}$ and FaDu/T-200 nM cells as evaluated through acridine orange and Hoechest 33342/PI double staining.

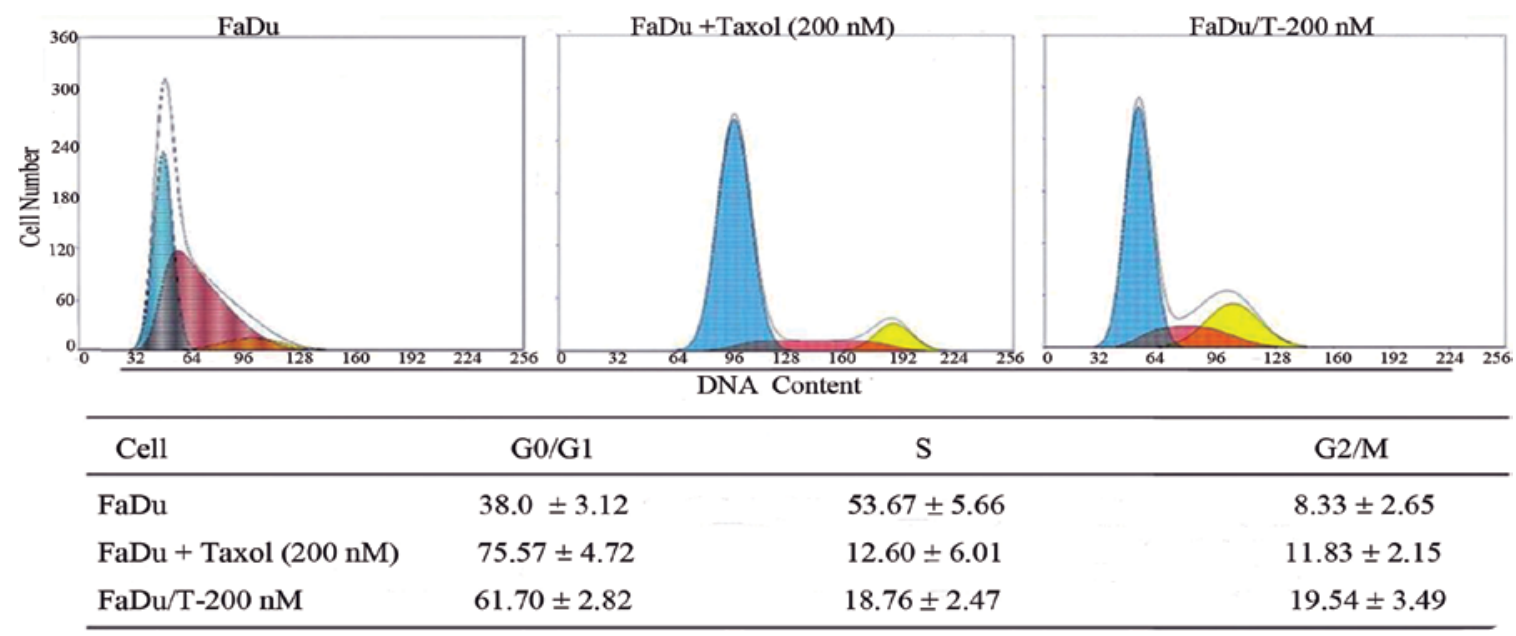

Figure 3. Cell cycle distributions of FaDu cells , FaDu/T-200 nM cells and FaDu cells stimulated by Taxol at $200 \mathrm{nM}$ for $24 \mathrm{~h}$ as detected by flow cytometry.
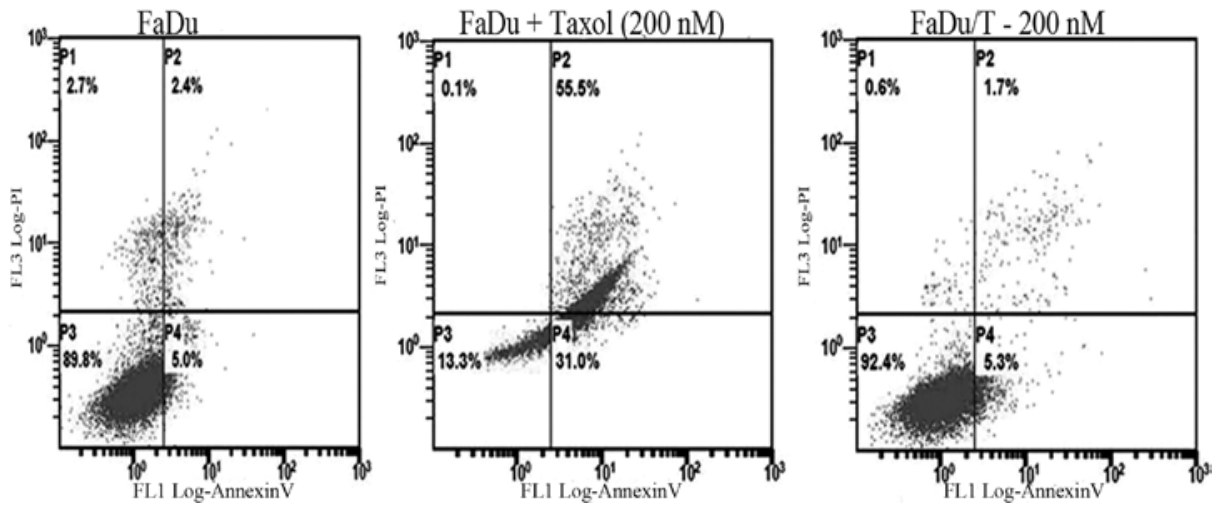

Figure 4. Cell apoptosis was analyzed in the FaDu cells, FaDu/T-200 nM cells and FaDu cells stimulated by Taxol at $200 \mathrm{nM}$ for $24 \mathrm{~h}$ by flow cytometry.

Apoptosis of the FaDu and FaDu/T cells induced by Taxol. Compared with the apoptotic rate of the untreated cells $(4.45 \pm 1.60 \%)$, the rates in the cells exposed to Taxol $(200 \mathrm{nM}$, $24 \mathrm{~h})$ and $\mathrm{FaDu} / \mathrm{T}$ cells whose tolerance to Taxol was $200 \mathrm{nM}$ were $32.9 \pm 2.39$ and $4.53 \pm 1.1 \%$, respectively (Fig. 4). These results further indicate that the anti-apoptosis function of $\mathrm{FaDu} / \mathrm{T}$ cells increased significantly.

mRNA levels of MDRI/ABCB1 and BCRP/ABCG2 in the $\mathrm{FaDu}$ and $\mathrm{FaDu} / \mathrm{T}$ cells. Compared with the untreated cells, 


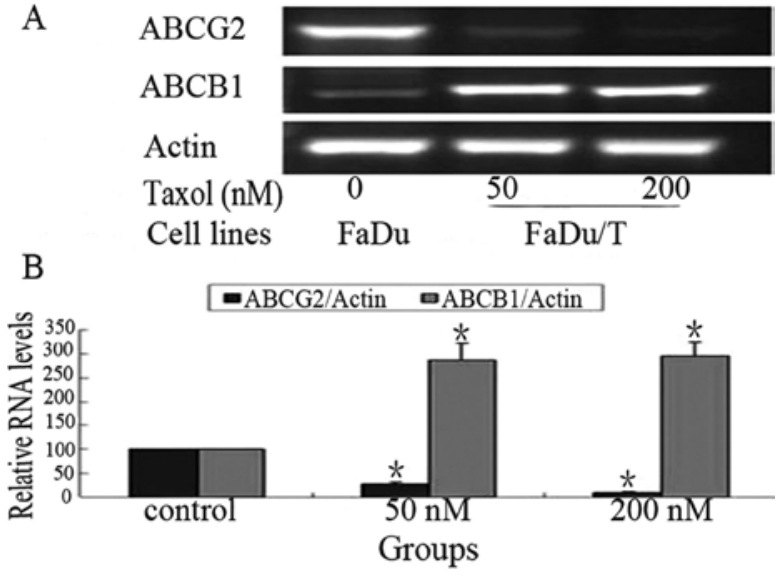

Figure 5. The mRNA levels of MDR1/ABCB1 and BCRP/ABCG2 in FaDu, $\mathrm{FaDu} / \mathrm{T}-50 \mathrm{nM}$ and $\mathrm{FaDu} / \mathrm{T}-200 \mathrm{nM}$ cells were determined by RT-PCR By densitometry, the mRNA expression of MDR1/ABCB1 increased but BCRP/ABCG2 reversely decreased in $\mathrm{FaDu} / \mathrm{T}$ cells compared with that in FaDu cells, particularly in the FaDu/T-200 nM cells ( $\left.{ }^{*} \mathrm{P}<0.05\right)$. (A) RT-PCR analysis of MDR1/ABCB1 and BCRP/ABCG2 in FaDu and FaDu/T cells. (B) Graphs show the quantification of DNA bands by densitometric scanning. The relative mRNA level was presented as the ratio of densities of MDR1/ABCB1 and BCRP/ABCG2 to actin bands. Results are expressed as the mean $\pm \operatorname{SD}(n=3)$.

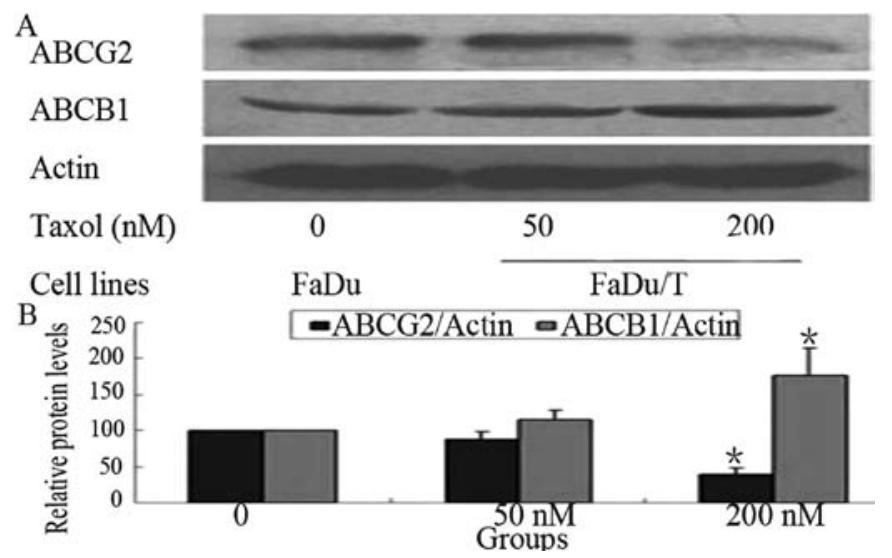

Figure 6. MDR1/ABCB1 and BCRP/ABCG2 protein levels in FaDu, FaDu/ $\mathrm{T}-50 \mathrm{nM}$ and $\mathrm{FaDu} / \mathrm{T}-200 \mathrm{nM}$ cells were detected by Western blot analysis. By densitometry, the protein expression of MDR1/ABCB1 increased while BCRP/ABCG2 was down-regulated in the $\mathrm{FaDu} / \mathrm{T}$ cells compared with that in the FaDu cells, particularly in the FaDu/T-200 nM cells ( $\mathrm{P}<0.05)$. (A) Protein analysis of MDR1/ABCB1 and BCRP/ABCG2 in FaDu and $\mathrm{FaDu} / \mathrm{T}$ cells. (B) Graphs show the quantification of DNA bands by densitometric scanning. The relative mRNA level was presented as the ratio of densities of MDR1/ABCB1 and BCRP/ABCG2 to actin bands. Results are expressed as the mean $\pm \mathrm{SD}(\mathrm{n}=3)$.

the mRNA level of MDR1/ABCB1 was up-regulated while BCRP/ABCG2 was decreased in the FaDu/T cells (Fig. 5A). Image $\mathbf{J}$ software was used to analyze the relative photodensity, using $\beta$-actin as a standard. Considereing the control as $100 \%$, the relative photodensity of MDR1/ABCB1 in the $\mathrm{FaDu} / \mathrm{T}-50 \mathrm{nM}$ and FaDu/T-200 nM cells was $286.17 \pm 37.41$ and $294.91 \pm 30.62 \%$, respectively. BCRP/ABCG2/actin of $\mathrm{FaDu} / \mathrm{T}$ was $26.35 \pm 4.28 \%(\mathrm{FaDu} / \mathrm{T}-50 \mathrm{nM})$ and $10.01 \pm 1.88 \%$ (FaDu/T-200 nM) considering the control as 100\% (Fig. 5B).

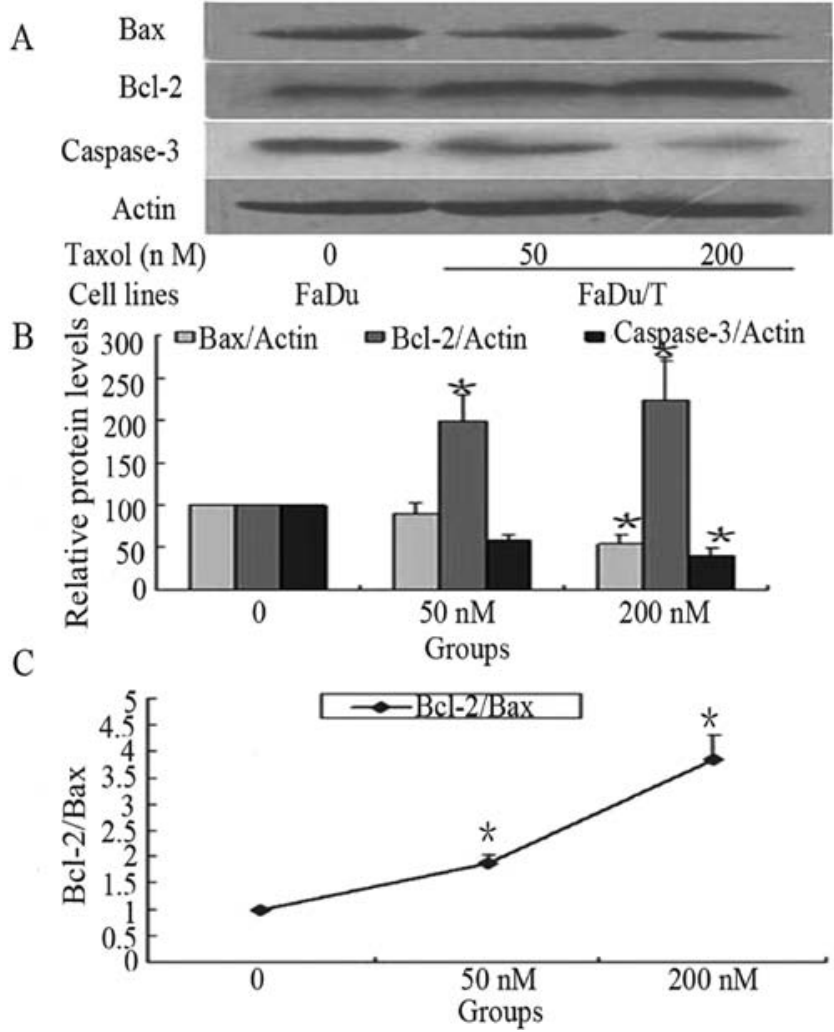

Figure 7. Expression of caspase-3, Bcl-2 and Bax was detected by Western blot analysis. (A) Representative Western blot analysis of the protein expression. Blots are representative of 3 separate experiments. (B) Graphs show the quantification of DNA bands by densitometric scanning. The relative protein level was presented as the ratio of densities of caspase-3, Bcl-2 or Bax to actin bands. Results are expressed as the mean $\pm \mathrm{SD}(\mathrm{n}=3)\left({ }^{*} \mathrm{P}<0.05\right)$. (C) The relative $\mathrm{Bcl}-2 / \mathrm{Bax}$ level was analyzed between different cells. Considering the control as 1.00, Bcl-2/Bax was $1.87 \pm 0.16 \mathrm{in} \mathrm{FaDu} / \mathrm{T}-50 \mathrm{nM}$ and $3.83 \pm 0.47$ in $\mathrm{FaDu} / \mathrm{T}-200 \mathrm{nM}$ cells $(\mathrm{P}<0.05)$.

Statistical analysis showed that a significant difference existed between the $\mathrm{FaDu}$ and $\mathrm{FaDu} / \mathrm{T}$ cells $(\mathrm{P}<0.05)$.

Changes in MDRI/ABCB1 and BCRP/ABCG2 protein levels. In comparison with the untreated FaDu cells, the expression of MDR1/ABCB1 was up-regulated while that of BCRP/ABCG2 was down-regulated when $\beta$-actin was taken as the standard in both the FaDu/T-50 nM and FaDu/T-200 nM cells (Fig. 6A). Image J software was used to analyze the relative photodensity. Considering the control as $100 \%$, the ratio of the density of $\mathrm{ABCB} 1 / \mathrm{actin}$ was $115.47 \pm 12.74 \%$ in the $\mathrm{FaDu} / \mathrm{T}-50 \mathrm{nM}$ and $176.86 \pm 37.88 \%$ in the $\mathrm{FaDu} / \mathrm{T}-200 \mathrm{nM}$ cells. The ABCG2/ actin level in the FaDu/T-50 nM cells was $87.20 \pm 11.81 \%$ and $39.26 \pm 9.08 \%$ in the FaDu/T-200 nM cells (Fig. 6B). Statistical analysis showed that a significant difference existed between the $\mathrm{FaDu}$ and $\mathrm{FaDu} / \mathrm{T}$ cells $(\mathrm{P}<0.05)$.

Caspase-3, Bcl-2 and Bax expression as assessed by Western blotting. In comparison with the untreated $\mathrm{FaDu}$ cells, the expression of caspase- 3 and Bax was up-regulated while that of Bcl-2 was down-regulated in both the FaDu/T-50 nM and $\mathrm{FaDu} / \mathrm{T}-200 \mathrm{nM}$ cells when $\beta$-actin was used as the standard (Fig. 7A). Image J software was used to analyze the relative photodensity. Considering the control as $100 \%$, the 
density ratio of caspase- 3 , Bcl-2 and Bax was $57.92 \pm 6.55$, $199.69 \pm 29.96$ and $89.03 \pm 13.56 \%$ in the $\mathrm{FaDu} / \mathrm{T}-50 \mathrm{nM}$ and $40.56 \pm 7.93,223.85 \pm 45.84$ and $53.82 \pm 11.17 \%$ in the $\mathrm{FaDu} / \mathrm{T}$ $200 \mathrm{nM}$ cells, respectively (Fig. 7B). The relative Bcl-2/Bax level was analyzed between the different cells and a significant increase was detected in the $\mathrm{FaDu} / \mathrm{T}$ cells compared with the control. Considering the control as 1.00, the ratio of Bcl-2/ Bax was $1.87 \pm 0.16$ in $\mathrm{FaDu} / \mathrm{T}-50 \mathrm{nM}$ and $3.83 \pm 0.47$ in the $\mathrm{FaDu} / \mathrm{T}-200 \mathrm{nM}$ cells (Fig. 7C). Statistical analysis showed that a significant difference was achieved between the $\mathrm{FaDu}$ and $\mathrm{FaDu} / \mathrm{T}$ cells $(\mathrm{P}<0.01)$. These results further explain the mechanism of anti-apoptosis in $\mathrm{FaDu} / \mathrm{T}$ cells.

\section{Discussion}

The major obstacle to tumor chemotherapy is drug resistance, including intrinsic and acquired resistance to multiple chemotherapeutic drugs, yet the mechanisms responsible for MDR remain unclear (7). To elucidate the mechanism responsible for MDR is critical. Here, we established a multidrug resistant cell line to Taxol $(\mathrm{FaDu} / \mathrm{T})$ by exposing normal $\mathrm{FaDu}$ cells to escalating concentrations of Taxol stepwise for over 12 months and investigated the basic characteristics of $\mathrm{FaDu} / \mathrm{T}$ cells in an effort to provide theoretical support for the study of the reversal of MDR in HNSCC.

Firstly, the multidrug resistance of $\mathrm{FaDu} / \mathrm{T}$ to DDP, 5-FU, Dox and VCR was assayed by MTT. Results showed varying degrees of resistance, respectively. Morphological changes were then analyzed by microscopic observation using phase contrast microscopy. The MDR cell line $\mathrm{FaDu} / \mathrm{T}$ grew significantly slower when compared with the parental cells as determined by morphological observation and growth curve analysis. The biological activity of Taxol is based on its ability to promote microtubule assembly and stabilize tubulin polymers against depolymerization. This arrests cells in the G2/M phase, inducing cell apoptosis (consequently, leaving the cells in the G0/G1 phase to survive). This may be the reason for the slower growth rate of $\mathrm{FaDu} / \mathrm{T}$ cells (8). Analysis of the cell cycle distribution by flow cytometry revealed an increased proportion of cells in the G0/G1 and G2/M phases in this study, which verified the growth curve analysis.

Upon acridine orange staining and Hoechst 33342/ PI double staining, FaDu/T cells showed powerful apoptosis resistance to Taxol compared with the control cells. Chromosome condensation and nuclear fragmentation were detected under fluorescence microscopy. Quantitative analysis of apoptosis by flow cytometry revealed a similar result, which further confirmed the anti-apoptotic ability of $\mathrm{FaDu} / \mathrm{T}$ cells. In general, the mechanism of apoptosis induced by Taxol involves Bcl-2, caspase-3, and the Fas/Fas ligand (9). Expression of caspase-3, Bcl-2 and $\mathrm{Bax}$ in $\mathrm{FaDu}$ and $\mathrm{FaDu} / \mathrm{T}$ cells was detected by Western blot analysis in this study, and significant alterations to resist apoptosis were detected. This further proves the anti-apoptosis of the MDR cells.

Many genes have been reported to be related with drug resistance or sensitivity, such as ATP-binding cassette (ABC) genes (10). The human has $49 \mathrm{ABC}$ genes, arranged in eight subfamilies and named through divergent evolution (11). The variable expression of $\mathrm{ABC}$ transporters results in ATP-driven efflux of antitumor drugs from cancer cells, thereby leading to decreased intracellular drug accumulation and consequent MDR (12). The main elements related to MDR include P-glycoprotein (P-gp) translated by MDR1/ABCB1, the multidrug-resistance protein (MRP1) and the breast cancer multi-drug resistance protein 1 (BCRP/ABCG2) (13).

In the present study we focused on MDR1/ABCB1 and BCRP/ABCG2. The overexpression of MDR1/ABCB1 has been reported to be associated with resistance to a wide range of anticancer drugs, including Taxol (14-17). Here, we assessed the mRNA and protein levels of MDR1/ABCB1 in the FaDu/T cells, and up-regulation was obviously detected in a dosedependent manner. Yet, there is a disagreement concerning the role of BCRP/ABCG2 during MDR progression and whether or not Taxol is a substrate of ABCG2. Studies have found that Taxol is not the substrate of BCRP/ABCG2 during MDR $(18,19)$. They reported, although a mutation at position $482 \mathrm{can}$ alter the substrate specificity of BCRP/ABCG2, Taxol was not the substrate of either wild-type BCRP/ABCG2 or its mutants (20). Meanwhile, various studies found that BCRP/ABCG2 was involved during MDR induced by Taxol $(21,22)$. At the gene and protein levels, we observed a decreased expression of BCRP/ABCG2 in the FaDu/T cells compared with the parental cells. For the first time we report the role of BCRP/ ABCG2 in MDR progression induced by Taxol in FaDu cells. Controversy concerning the relationship between MDR1/ $\mathrm{ABCB} 1$ and $\mathrm{BCRP} / \mathrm{ABCG} 2$ during MDR also exists. A recent study reported the inverse trend of expression between $\mathrm{ABCB} 1$ and ABCG2 mRNA at the blood-brain barrier in ABCB1 (-/-) and ABCG2 (-/) knockout mice (23). Other studies have also demonstrated an inverse relationship between them $(24,25)$. Meanwhile, a positive relationship between MDR1/ABCB1 and BCRP/ABCG2 expression has also been reported $(26,27)$. According to RT-PCR and Western blot analysis, we reported that the levels of two transporters in $\mathrm{FaDu}$ and $\mathrm{FaDu} / \mathrm{T}$ cells were MDR1/ABCB1: $\mathrm{FaDu}<\mathrm{FaDu} / \mathrm{T}$ whereas BCRP/ABCG2: $\mathrm{FaDu}>\mathrm{FaDu} / \mathrm{T}$, respectively. When the cancer cells were exposed to the chemotherapy drugs, due to coexpression, inverse or positive relationships among the $\mathrm{ABC}$ transporters have not been particularly investigated. It could be hypothesized that to protect the cells from cytokine-induced oxidative damage, the lack of a specific gene may be offset by expression and protein synthesis of another compensatory gene. The variable expression of $\mathrm{ABC}$ transporters may be regulated in an abnormal manner in the presence of an anticancer drug. The mechanism involved in the decreased expression level of BCRP/ABCG2 in $\mathrm{FaDu} / \mathrm{T}$ cells warrants further studied.

In conclusion, the MDR cell line $\mathrm{FaDu} / \mathrm{T}$ provides us with a base for the further study of the resistant mechanisms of clinical HNSCC drug resistance. Further study must be carried out on the mechanism involved in the reversed trend of molecular expression between $\mathrm{ABCB} 1$ and $\mathrm{ABCG} 2$ in $\mathrm{FaDu} / \mathrm{T}$ cells, which would be valuable for the prevention of MDR in clinical cancer chemotherapy.

\section{Acknowledgements}

This study was supported by the Shandong Provincial Outstanding Young Scientist Research Award Fund of China (no. 03BS020). 


\section{References}

1. Hoffman HT, Porter K, Karnell LH, Cooper JS, Weber RS, Langer CJ, Ang KK, Gay G, Stewart A and Robinson RA: Laryngeal cancer in the United States: changes in demographics, patterns of care, and survival. Laryngoscope 116 $1-13,2006$

2. Friboulet L, Pioche-Durieu C, Rodriguez $S$, Valent $A$, Souquère $S$, Ripoche H, Khabir A, Tsao SW, Bosq J, Lo KW and Busson P: Recurrent overexpression of c-IAP2 in EBV-associated nasopharyngeal carcinomas: critical role in resistance to Toll-like receptor 3-mediated apoptosis. Neoplasia 10: 1183-1194, 2008.

3. Clark JI, Hofmeister C, Choudhury A, Matz G, Collins S, Bastian R, Melian E, Emami B and Petruzzelli G: Phase II evaluation of paclitaxel in combination with carboplatin in advanced head and neck carcinoma. Cancer 92: 2334-2340, 2001.

4. Crown J and O'Leary M: The taxanes: an update. Lancet 355: $1176-1178,2000$.

5. Baguley BC: Multiple drug resistance mechanisms in cancer. Mol Biotechnol 46: 308-316, 2010.

6. O'Connor R: The pharmacology of cancer resistance. Anticancer Res 27: 1267-1272, 2007.

7. Longley DB and Johnston PG: Molecular mechanisms of drug resistance. J Pathol 205: 275-292, 2005.

8. Rowinsky EK, Donehower RC, Jones RJ and Tucker RW: Microtubule changes and cytotoxicity in leukemic cell lines treated with Taxol. Cancer Res 48: 4093-4100, 1988.

9. Zhang X, Wang X, Song X, Liu C, Shi Y, Wang Y, Afonja O, $\mathrm{Ma}$ C, Chen YH and Hang L: Programmed cell death 4 enhances chemosensitivity of ovarian cancer cells by activating death receptor pathway in vitro and in vivo. Cancer Sci 101: 2163-2170, 2010.

10. Rodrigues AC, Curi R, Genvigir FD, Hirata MH and Hirata RD: The expression of efflux and uptake transporters are regulated by statins in Caco-2 and HepG2 cells. Acta Pharmacol Sin 30: 956-964, 2009.

11. Stavrovskaya AA and Stromskaya TP: Transport proteins of the ABC family and multidrug resistance of tumor cells Biochemistry 73: 592-604, 2008.

12. Vasiliou V, Vasiliou K and Nebert DW: Human ATP-binding cassette (ABC) transporter family. Hum Genomics 3: 281-290, 2009.

13. Daood M, Tsai C, Ahdab-Barmada $M$ and Watchko JF: ABC transporter (P-gp/AB-CB1, MRP1/ABCC1, BCRP/ABCG2) expression in the developing human CNS. Neuropediatrics 39: 211-218, 2008

14. Abraham I, Jain S, Wu CP, Khanfar MA, Kuang Y, Dai CL, Shi Z, Chen X, Fu L, Ambudkar SV, El Sayed K and Chen ZS: Marine sponge-derived sipholane triterpenoids reverse P-glycoprotein (ABCB1)-mediated multidrug resistance in cancer cells. Biochem Pharmacol 80: 1497-1506, 2010.
15. Cole SP, Sparks KE, Fraser K, Loe DW, Grant CE, Wilson GM and Dee-ley RG: Pharmacological characterization of multidrug resistant MRP-transfected human tumor cells. Cancer Res 54: 5902-5910, 1994.

16. Choi $\mathrm{CH}$ : $\mathrm{ABC}$ transporters as multidrug resistance mechanisms and the development of chemosensitizers for their reversal. Cancer Cell Int 5: 30, 2005.

17. Hughes $\mathrm{J}$ and Crowe A: Inhibition of P-glycoprotein-mediated efflux of digoxin and its metabolites by macrolide antibiotics. J Pharmacol Sci 113: 315-324, 2010.

18. Robey RW, Honjo Y, Morisaki K, Nadjem TA, Runge S, Risbood M, Poruchynsky MS and Bates SE: Mutations at aminoacid 482 in the ABCG2 gene affect substrate and antagonist specificity. Br JCancer 89: 1971-1978, 2003.

19. Allen JD and Schinkel AH: Multidrug resistance and pharmacological protection mediated by the breast cancer resistance protein (BCRP/ABCG2). Mol Cancer Ther 1: 427-434, 2002.

20. Litman T, Brangi M, Hudson E, Fetsch P, Abati A, Ross DD, Miyake K, Resau JH and Bates SE: The multidrug-resistant phenotype associated with overexpression of the new ABC halftransporter, MXR (ABCG2). J Cell Sci 113: 2011-2021, 2000

21. Robey RW, Medina-Pérez WY, Nishiyama K, Lahusen T, Miyake K, Litman T, Senderowicz AM, Ross DD and Bates SE: Overexpression of the ATP-binding cassette half-transporter, ABCG2 (Mxr/BCrp/ABCP1), in flavopiridol-resistant human breast cancer cells. Clin Cancer Res 7: 145-152, 2001.

22. Liu T, Xu F, Du X, Lai D, Liu T, Zhao Y, Huang Q, Jiang L, Huang W, Cheng W and Liu Z: Establishment and characterization of multi-drug resistant, prostate carcinoma-initiating stem-like cells from human prostate cancer cell lines 22RV1. Mol Cell Biochem 340: 265-273, 2010.

23. Cisternino S, Mercier C, Bourasset F, Roux F and Scherrmann JM: Expression, up-regulation and transport activity of the multidrug-resistance protein Abcg2 at the mouse blood-brain barrier. Cancer Res 64: 3296-3301, 2004.

24. Choi CH, Kim HS, Rha HS, Jeong JH, Park YH, Min YD, Kee KH and Lim DY: Drug concentration-dependent expression of multidrug resistance-associated protein and P-glycoprotein in the doxorubicin-resistant acute myelogenous leukemia sublines. Mol Cells 9: 314-319, 1999.

25. Friedrich RE, Punke $C$ and Reymann A: Expression of multidrug resistance genes (ABCB1, mrp1, ABCG2) in primary oral squamous cell carcinoma. In Vivo 18: 133-147, 2004

26. Galimberti S, Guerrini F, Palumbo GA, Consoli U, Fazzi R, Morabito F, Santini V and Petrini M: Evaluation of ABCG2 and MDR-1 co-expression by quantitative molecular assessment in AML patients. Leuk Res 28: 367-372, 2004.

27. Kanzaki A, Toi M, Nakayama K, Bando H, Mutoh M, Uchida T, Fukumoto $\mathrm{M}$ and Takebayashi $\mathrm{Y}$ : Expression of multidrug resistance-related transporters in human breast carcinoma. Jpn J Cancer Res 92: 452-458, 2001. 